\title{
Importance Rearrangement within Education, Economy and Natural Protection Ministries for Armenian Composite Supportive Progress (ACASP)
}

\author{
Azniv F. Petrosyan ${ }^{1,2}$ \\ ${ }^{1} \mathrm{PhD}$, Department of Geography \& Regional Planning, School of Rural \& Surveying Engineering, National Technical \\ University of Athens, 15780 Zographou Campus, Athens, Greece \\ ${ }^{2}$ Independent Armenian Researcher, Zeytun, 375069, Yerevan, Armenia \\ Correspondence: Azniv F. Petrosyan, Department of Geography \& Regional Planning, School of Rural \& Surveying \\ Engineering, National Technical University of Athens, 15780 Zographou Campus, Athens, Greece.
}

Received: August 11, 2016

doi:10.11114/bms.v2i3.1834
Accepted: August 19, $2016 \quad$ Online Published: August 23, 2016

URL: http://dx.doi.org/10.11114/bms.v2i3.1834

\begin{abstract}
Sustainable Development is an innovative concept characterized as Composite Appraising Supportive Progress of Armenia (ACASP). Biodiversity concept is another topic having a vast power on public management and employment. Social, economic and environmental impacts optimize sequences within Education $\left(\mathrm{S}_{3}\right)$, Economy $\left(\mathrm{E}_{5}\right)$, Air $\left(\mathrm{N}_{3}\right)$ \& Land $\left(\mathrm{N}_{1}\right)$ Ministries. Seven (7) phases of Operation Research (OR) studies correspond to nine (9) procedures of composite progressive indicators. Two (2) techniques are applied as decision making of utility function and transportation tasks. North-West Corner Rule (NWCR) and Low Cost Cell Rule (LCCR) are applied to manage public employment as per Education $\left(\mathrm{S}_{3}\right)$, Economy $\left(\mathrm{E}_{5}\right)$, Land $\left(\mathrm{N}_{1}\right)$ and Air $\left(\mathrm{N}_{3}\right)$ magnitudes of ACASP.

A motivating approach is pertained not only to pick the order of significance as per biodiversity concept, but also to characterize the process of decision making through operation research techniques, particularly transportation assignments as per origins and destinations with supply and demand applications. The resulting sequence is revealed by sustenance of biodiversity concept with public employment of Armenian CASP.
\end{abstract}

Keywords: Armenian Composite Appraising Supportive Progress (ACASP), sustainable as bio-diverse development, decision making, public employment, operation research, transportation assignments, Composite Progressive Indicators (CPI)

\section{Introduction}

Petrosyan $(2014,2010,2005)$ exposes the worldwide researches centralizing on three (3) ways of Sustainable Development (SD) depictions. A modern concern is examined in four (4) magnitudes of Sustainable Development (SD) as Composite Appraising Supportive Progress (CASP) utilizing Biodiversity concept (Nijkamp and Vindigni, 2003) and Operation Research (OR) characteristics (Midgley and Reynolds, 2004) in Table 1. The main emphasis of the current paper is to compose a decision making for the public management and employment (F) based on not only Decision Trees \& Utility Theories but also transportation tasks using Northwest Corner Rule / Low Cost Methods on Education $\left(\mathrm{S}_{3}\right)$, Economy $\left(\mathrm{E}_{5}\right)$, Land $\left(\mathrm{N}_{1}\right)$ and Air $\left(\mathrm{N}_{3}\right)$ magnitudes of ACASP.

Table 1. Portrayal of SD, ACASP, OR Characteristics and Biodiversity Concept

\begin{tabular}{|c|c|c|c|c|c|}
\hline No & SD/ Management & $\begin{array}{l}\text { Biodiversity } \\
\text { Concept }\end{array}$ & $\begin{array}{l}\text { OR Chara- } \\
\text { cteristics }\end{array}$ & OR Design Approach & References \\
\hline & \multicolumn{2}{|c|}{ Petrosyan $(2014,2010,2005)$} & \multicolumn{2}{|c|}{ Midgley and Reynolds (2004) } & Petrosyan $(2014)$ \\
\hline$\alpha$. & Society (S) / Education & Genes & Interdisciplinary & Boundary Critique & $\begin{array}{l}\text { Holistic Illustration of SD Framework } \\
\text { (Lyytimaki and Rosenstrom, 2008) }\end{array}$ \\
\hline$\beta$. & Economy (E) / Economy & Species & $\begin{array}{l}\text { Systems } \\
\text { Orientation }\end{array}$ & Improvement & $\begin{array}{c}\text { SD Proposed by Russian Dolls Model } \\
\text { (Levett, 1998) }\end{array}$ \\
\hline$\gamma$ & $\begin{array}{l}\text { Environment }(\mathrm{N}) / \\
\text { Natural Protection }\end{array}$ & Ecosystem & Purposefulness & Methodological Pluralism & $\begin{array}{c}\text { Primary Concept of SD (Walton etc, } \\
\text { 2005) }\end{array}$ \\
\hline$\delta$. & $\begin{array}{l}\text { Sustainability / Public } \\
\text { Employment }\end{array}$ & Functions & $\begin{array}{l}\text { Transportation } \\
\text { Tasks }\end{array}$ & $\begin{array}{c}\text { Northwest Corner / Low } \\
\text { Cost Methods }\end{array}$ & ACASP (Petrosyan 2015 a,b,c, 2014) \\
\hline
\end{tabular}

Source: $<$ http://redfame.com/> own case study 


\section{Literature Review}

Sustainability is considered as one of the biggest worldwide challenges in the twenty-first century and it is widely believed that the nations which disregard this fact are subject to various problems in the long term (Riasi and Pourmiri, 2016). Even though sustainability has never been accurately resolved, Composite Appraising Supportive Progress (CASP) is a recent index to assess Combined Sustainable Development Index (CSDI). Three (3) incorporated magnitudes, i.e., society, economy and nature, are portrayed in the book of Petrosyan (2014) and the paper of Petrosyan (2010) with six (6) Armenian categories as per each magnitude for Republic of Armenia (RA) and Nagorno-Karabakh Republic ministries and areas as in Table 2 and Figure 1.

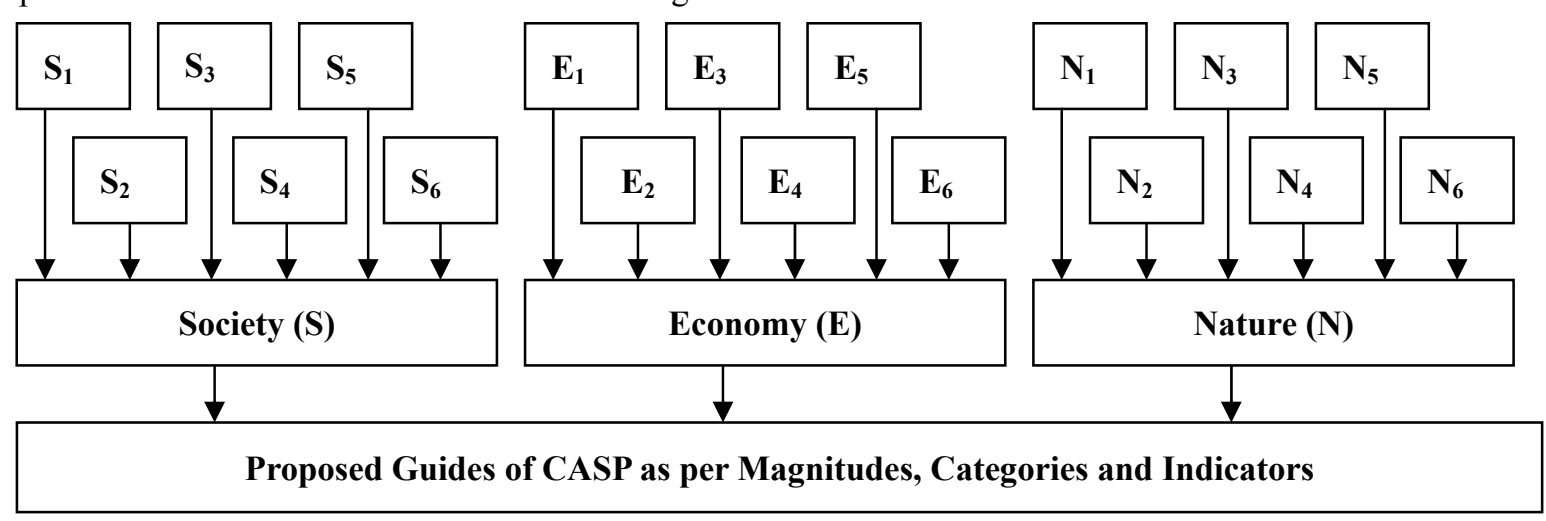

Figure 1. Proposed Guides of CASP as per Magnitudes, Categories and Indicators

Source: Petrosyan (2014)

Runge (2012) observes the Decision Trees \& the Utility Theories with sum of multiplication of pertinent utility function $\left(\mathrm{U}_{\mathrm{i}}\right)$ and probability $\left(\mathrm{P}_{\mathrm{i}}\right)$ in $(1)$.

$$
D M_{i}=\sum_{i=1}^{n} P_{i} U_{i}
$$

Perceptions of Synthetic Measure (SM) or variation of Decision Making (DM) are accomplished by Balcerzak (2015) in (2) as per Utility function $\left(U_{i}\right)$ of already described subcategories within an applicable category with its equally distributed probabilities $\left(\mathrm{P}_{\mathrm{i}}\right)$ and the number $(\mathrm{n})$ of Utility Function.

$$
D M_{i}=S M_{i}=\left(\sum_{i=1}^{n} U_{i}\right) / n
$$

Murthy (2007) prescribes the subject of operations research as a branch of applied mathematics, used to supply a scientific support for economic management and to make decisions to the specified problems on-time and efficiently. The universal approach is to investigate the economic issues and to execute the solution while considering the other aspects, i.e. human, social and political constraints. An attractive approach is applied through operation research techniques to ACASP while transforming composite progressive indicators (Petrosyan, 2015d) into solving the transportation problems.

Gupta and Cozzolino (1975) portrays five (5) elements to transportation problems as:

1.A set of m origins: $\mathrm{O}_{1}, \mathrm{O}_{2}, \ldots, \mathrm{O}_{\mathrm{m}}$;

2.A set of n destinations: $\mathrm{D}_{1}, \mathrm{D}_{2}, \ldots \mathrm{D}_{\mathrm{n}}$;

3. A set of supplies of indistinguishable units: $\mathrm{a}_{1}-\mathrm{O}_{1}, \mathrm{a}_{2}-\mathrm{O}_{2}, \mathrm{a}_{\mathrm{m}}-\mathrm{O}_{\mathrm{m}}$;

4. A set of requirements: $b_{1}-D_{1}, b_{2}-D_{2}, b_{m}-D_{m}$;

5. A set of unit shipment costs: $c_{i j}$ is the cost of shipping 1 unit from $O_{i}$ to $D_{j}$ with $m \times n$ such costs as inputs.

The total cost of the shipment schedule is represented in (3) as a function of the decision variables.

$$
\operatorname{Min} Z=\sum_{i=1}^{m} \sum_{j=1}^{n} c_{i j} x_{i j}
$$


Table 2. Armenian Categories Representation of CASP - RA \& NKR Ministries \& Areas

\begin{tabular}{|c|c|c|c|c|}
\hline No & $\begin{array}{l}\text { Armenian } \\
\text { Categories } \\
\text { y (S) }\end{array}$ & $\begin{array}{c}\text { CASP } \\
\text { Categories }\end{array}$ & Ministries & Areas \\
\hline $\mathrm{S}_{1}$ & Demography & Humans & $\begin{array}{l}\text { Ministry of Territorial Administration and } \\
\text { Emergency Situations http://www.mta.gov.am }\end{array}$ & Askeran Marz \\
\hline $\mathrm{S}_{2}$ & Employment & Society Concerns & $\begin{array}{l}\text { Ministry of Labor and Social Affairs } \\
\text { http://www.mlsa.am }\end{array}$ & Syunik Marz \\
\hline $\mathrm{S}_{3}$ & Education & $\begin{array}{l}\text { Knowledge in } \\
\text { Practice }\end{array}$ & $\begin{array}{l}\text { Ministry of Education and Science } \\
\mathrm{http}: / / \text { www.edu.am }\end{array}$ & Shirak Marz \\
\hline $\mathrm{S}_{4}$ & Science & Space Science & Ministry of Defence http://www.mil.am/ & Lori Marz \\
\hline $\mathrm{S}_{5}$ & Economic Activitie & $\begin{array}{l}\text { Political } \\
\text { Performance }\end{array}$ & $\begin{array}{l}\text { National Assembly of the Republic of } \\
\text { Armenia http://parliament.am/ }\end{array}$ & Yerevan Marz \\
\hline $\mathrm{S}_{6}$ & $\begin{array}{l}\text { Transport } \\
\text { Communication }\end{array}$ & Transport & $\begin{array}{l}\text { Ministry of Transport and Communication } \\
\mathrm{http} / / / \text { www.mtc.am }\end{array}$ & $\begin{array}{l}\text { Vayots-Dzor } \\
\text { Marz }\end{array}$ \\
\hline \multicolumn{5}{|c|}{ Economy $(\mathbf{E})$} \\
\hline $\mathrm{E}_{1}$ & Finances & Investment & Ministry of Finance http://www.minfin.am/ & Qashatagh Marz \\
\hline $\mathrm{E}_{2}$ & Living Conditions & Human Standards & Ministry of Culture http://www.mincult.am & Armavir Marz \\
\hline$E_{3}$ & Prices Tariffs & $\begin{array}{l}\text { Production - } \\
\text { Consumption }\end{array}$ & $\begin{array}{l}\text { Ministry of Urban Development } \\
\text { http://www.mud.am/ }\end{array}$ & Shushi Marz \\
\hline $\mathrm{E}_{4}$ & Agriculture & Agriculture & Ministry of Agriculture www.minagro.am/ & Ararat Marz \\
\hline $\mathrm{E}_{5}$ & Industry & Industry & Ministry of Economy www.mineconomy.am & Aragatsotn Marz \\
\hline $\mathrm{E}_{6}$ & Trade and Services & Tourism & $\begin{array}{l}\text { Ministry of Diaspora mindiaspora.am } \\
\text { Ministry of Foreign Affairs mfa.am }\end{array}$ & Martuni Marz \\
\hline \multicolumn{5}{|c|}{ Nature (N) } \\
\hline $\mathrm{N}_{1}$ & \multicolumn{2}{|c|}{ Land } & & Hadrut Marz \\
\hline $\mathrm{N}_{2}$ & \multicolumn{2}{|c|}{ Water } & Ministry of Nature Protection & Gegharkuniq \\
\hline $\mathrm{N}_{3}$ & \multicolumn{2}{|c|}{ Air } & http://www.mnp.am & Martakert \\
\hline $\mathrm{N}_{4}$ & \multicolumn{2}{|c|}{ Biodiversity } & & Tavush Marz \\
\hline $\mathrm{N}_{5}$ & \multicolumn{2}{|c|}{ Energy } & $\begin{array}{l}\text { Ministry of Energy and Natural Resources } \\
\text { www.minenergy.am/en }\end{array}$ & Kotayk Marz \\
\hline $\mathrm{N}_{6}$ & \multicolumn{2}{|c|}{ Eco-Resources } & Ministry of Nature Protection http://www.mnp.am & $\begin{array}{l}\text { Shahumyan } \\
\text { Marz }\end{array}$ \\
\hline
\end{tabular}

Source: Petrosyan (2016)

The supply constraints are applied in (4).

The demand constraints are computed in (5).

$$
\sum_{j=1}^{n} x_{i j}=a_{i} \text { for }(i=1, \ldots, m)
$$

$$
\sum_{i=1}^{m} x_{i j}=b_{j} \text { for }(j=1, \ldots, n)
$$

The diagram for the methods for finding feasible solution is depicted in Figure 2.

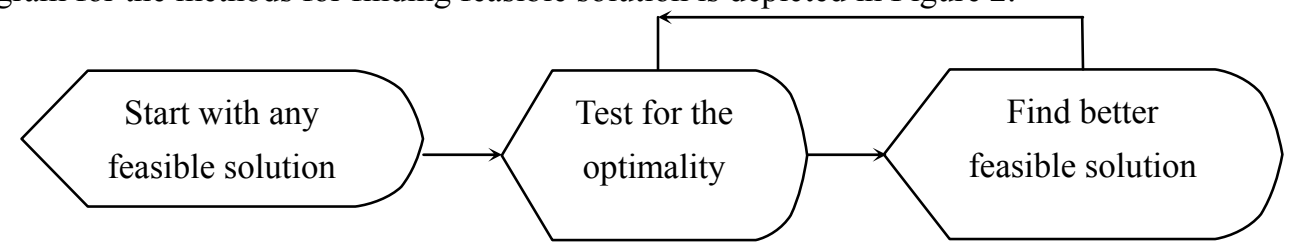

Figure 2. Methods for Finding Feasible Solution

Source: Gupta and Cozzolino (1975)

\section{Materials and Methods}

\subsection{Study Area}

Armenia (Figure 3) is located in the southern Caucasus and covers approximately 10\% of the Armenian upland (29,800 $\mathrm{km}^{2}$ ). Mainly, the military phase complies with theoretical and logic asymmetric conflicts during 1992-1994 over Nagorno-Karabakh with specific factors led to victory (Deriglazova and Minasyan, 2011). Nowadays, Nagorno-Karabakh Republic, i.e. Artsakh, (Figure 3) is a smaller $\left(4400 \mathrm{~km}^{2}\right)$ autonomous area between Armenia and Azerbaijan. Armenia and Nagorno-Karabakh support diversity of landscapes with a range of species, due to their geographic position (Arakelyan and Parham, 2008). ARMSTAT (2015) represents statistic data for eleven (11) Armenian areas and NKRSTAT (2015) presents seven (7) areas of Nagorno Karabakh Republic as depicted in Figure 3. 


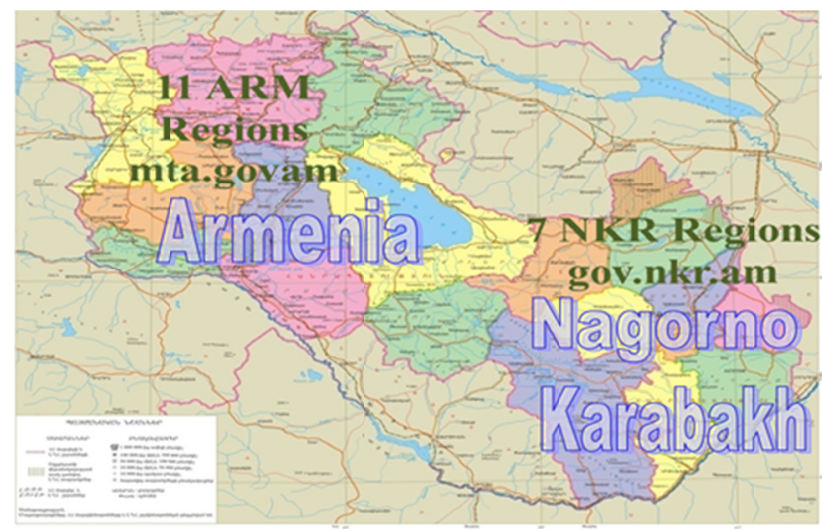

Figure 3. Map of eleven (11) Armenian and seven (7) Nagorno-Karabakh areas

Source: Petrosyan (2016)

\subsection{Data Sets}

Eighteen (18) categories are reviewed for Armenian Composite Supportive Progress (ACASP) in Table 2 and Figure 1, as per Armenian or Nagorno-Karabakh areas. The current paper prescribes management as process of preservations, activities and interactions between biodiversity stages (Petrosyan, 2014). Data sets and indicators options are offered as per ministries of Republic of Armenia (RA) in Table 3.

Table 3. Data Sets and Indicators Options as per Corresponding Ministry of RA

\begin{tabular}{|c|c|c|c|c|c|}
\hline No & $\begin{array}{l}\text { SD } \\
\text { magnitudes }\end{array}$ & $\begin{array}{c}\text { Biodiversity } \\
\text { Concept }\end{array}$ & Management & Ministry & Area / Figure \\
\hline$\alpha$. & Society (S) & Genes & Education $\left(\mathrm{S}_{3}\right)$ & $\begin{array}{l}\text { Ministry of Education and } \\
\text { Sciencewww.edu.am }\end{array}$ & $\begin{array}{ll}\text { Shirak } & \text { Marz } \\
\text { Figure } 4 & \end{array}$ \\
\hline$\beta$. & Economy (E) & Species & Economy $\left(\mathrm{E}_{5}\right)$ & $\begin{array}{l}\text { Ministry of Economy } \\
\text { www.mineconomy.am }\end{array}$ & $\begin{array}{l}\text { Aragatsotn Marz } \\
\text { Figure } 5\end{array}$ \\
\hline$\gamma$ & $\begin{array}{l}\text { Environment } \\
(\mathrm{N})\end{array}$ & Ecosystem & Land $\left(\mathrm{N}_{1}\right)$ & $\begin{array}{l}\text { Ministry of Nature Protection } \\
\mathrm{http} / / \text { www.mnp.am }\end{array}$ & $\begin{array}{l}\text { Hadrut } \quad \text { Marz } \\
\text { Figure } 6\end{array}$ \\
\hline & & & $\operatorname{Air}\left(\mathrm{N}_{3}\right)$ & & $\begin{array}{l}\text { Martakert Marz } \\
\text { Figure } 7\end{array}$ \\
\hline$\delta$. & Sustainability & Functions & $\begin{array}{l}\text { Public } \\
\text { (ACASP) }\end{array}$ & $\begin{array}{l}\text { State Employment Agency } \\
\text { www.emplyment.am }\end{array}$ & $\begin{array}{l}\text { Yerevan } \quad \text { Marz } \\
\text { Figure } 8\end{array}$ \\
\hline
\end{tabular}

Source: Petrosyan (2016)

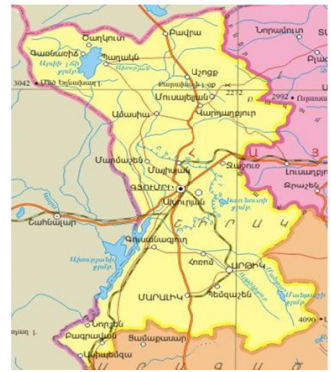

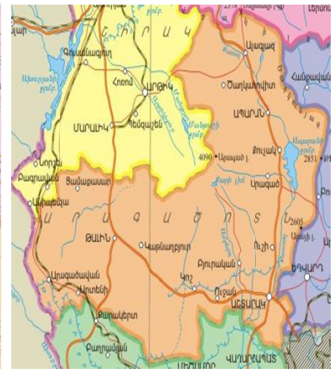

Figure 5. E5 Aragatsotn Marz

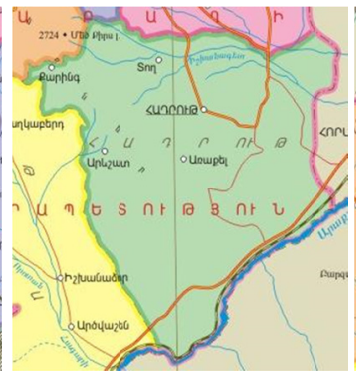

Figure 6. N1Hadrut Marz
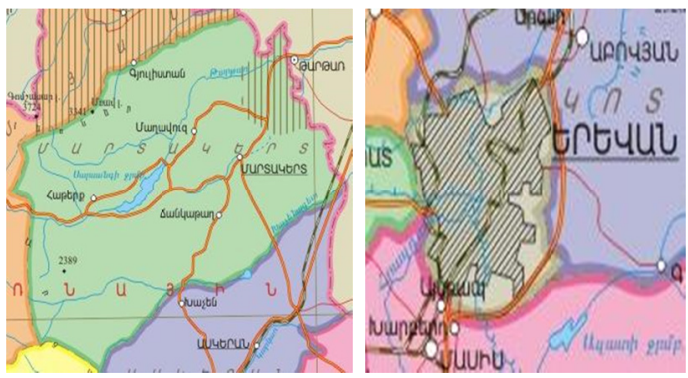

Figure 7. N3Martakert Marz Figure 8. ACASP Yerevan

Source: Petrosyan (2016), Petrosyan (2016), Petrosyan (2016), Petrosyan (2016), Petrosyan (2016).

\subsection{Methodology}

Hillier \&Liberman (2001) summarizes seven (7) phases of an Operation Research (OR) studies related to nine (9) Petrosyan $(2015 d \& 2016)$ procedures of composite progressive indicators. The current methodology of the current paper has several steps, showing strong emphasis on sustainable development and the composite appraisal of supportive progress as:

(1) Define the problem-operation research approaches as per ACASP;

(2) Gather relevant data-data collection performance through already created magnitudes, categories, sub-categories and indicators of ACASP;

(3) Formulate a mathematical model-transportation problem definition through transshipment approaches of ACASP;

(4) Develop procedures for deriving solutions - prescription to origins, destinations, supplies and demands in transportation revision for ACASP; 
(5) Test and refine the model-implementations of Northwest Comer Rule and Low-Cost Cell Methods for ACASP;

(6) Prepare ongoing applications - computation of total cost as per categorical indicators of ACASP.

(7) Implement - choice of the best solution using aforementioned operation research approaches of ACASP.

\section{Results}

\subsection{Education $\left(S_{3}\right)$-Shirak Marz}

\subsubsection{Data Sets Retrievals}

Petrosyan (2016) describes the methodology of data sets retrieval from Republic of Armenia (RA) Ministry of Education and Science (MES) and guides to the summarized results of the first $\left(1^{\text {st }}\right)$ and the second $\left(2^{\text {nd }}\right)$ versions of data retrievals for Education $\left(\mathrm{S}_{3}\right)$-Shirak Marz in Figure 4 \& Table 4.

Table 4. $1^{\text {st }} \& 2^{\text {nd }}$ Versions of Data Retrievals for Education $\left(\mathrm{S}_{3}\right)$-Shirak Marz

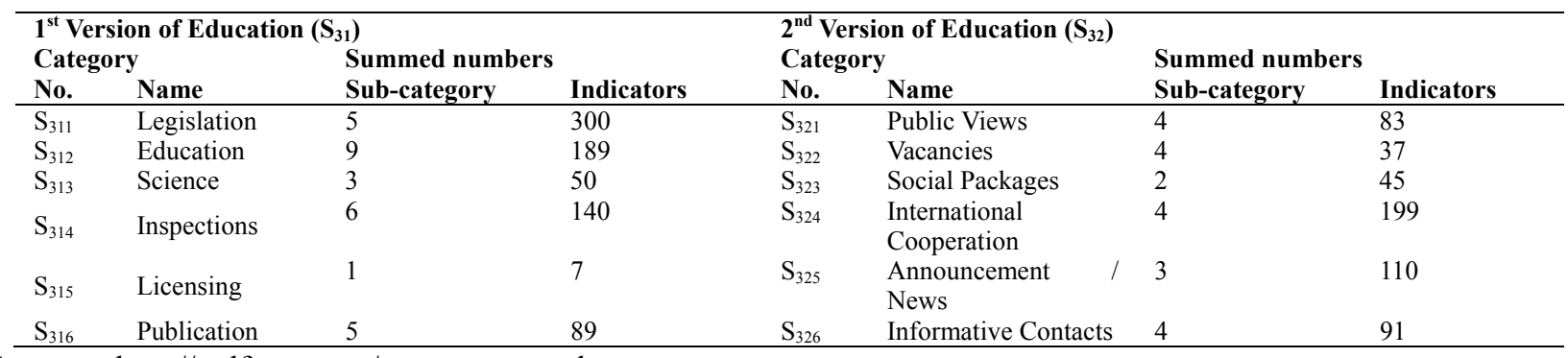

Source: $<$ http://redfame.com/>own case study

4.1.2 Decision Making as Utility Function of Education $\left(\mathrm{S}_{3}\right)$ Magnitude

Decision Making as Utility Function of Education $\left(\mathrm{S}_{3}\right)$ Magnitude is computed as per (2). The results of $\mathrm{DM}_{\mathrm{i}}$ are provided in Table 5 for the $1^{\text {st }}$ and the $2^{\text {nd }}$ versions of Education $\left(\mathrm{S}_{3}\right)$ Magnitude-Shirak Marz.

Table 5. $1^{\text {st }}$ and $2^{\text {nd }}$ Versions of Decision Making $\left(\mathrm{DM}_{\mathrm{i}}\right)$ Computation for Education $\left(\mathrm{S}_{3}\right)$

\begin{tabular}{|c|c|c|c|c|c|c|c|}
\hline \multicolumn{3}{|c|}{ Magnitude (Category) } & \multirow{2}{*}{$\mathbf{D M}_{\mathbf{i}}$} & \multicolumn{3}{|c|}{ Magnitude (Category) } & \multirow{2}{*}{$\mathbf{D M}_{\mathbf{i}}$} \\
\hline No. & Name & Range & & No. & Name & Range & \\
\hline $\mathrm{S}_{311}$ & Legislation & 1 & 60 & $\mathrm{~S}_{321}$ & Public Views & 5 & 20.75 \\
\hline $\mathrm{S}_{312}$ & Education & 3 & 21 & $\mathrm{~S}_{322}$ & Vacancies & 6 & 9.25 \\
\hline $\mathrm{S}_{313}$ & Science & 5 & 16.67 & $\mathrm{~S}_{323}$ & Social Packages & 3 & 22.5 \\
\hline $\mathrm{S}_{314}$ & Inspections & 2 & 23.33 & $\mathrm{~S}_{324}$ & Global Cooperation & 1 & 49.75 \\
\hline $\mathrm{S}_{315}$ & Licensing & 6 & 7 & $\mathrm{~S}_{325}$ & Announcement / News & 4 & 22 \\
\hline $\mathrm{S}_{316}$ & Publication & 4 & 17.8 & $\mathrm{~S}_{326}$ & Informative Contacts & 2 & 22.75 \\
\hline
\end{tabular}

Source: Petrosyan (2016)

4.1.3 Constructions of Operation Research Approaches as Transportation Problem for Education $\left(\mathrm{S}_{3}\right)$ Magnitude

An interesting approach is retrieved from Petrosyan (2016) paper and Gupta \& Cozzolino (1975) book. Data sets are represented in Table 6 by Origins as numbers of existing indicators and Destinations as active categories of Education $\left(\mathrm{S}_{3}\right)$ Magnitude.

Data sets are sustained as per initial order, derived from Table 4 and exemplified in Table 6. Another interesting approach is viewed in Table 7 through data sets representation with Origins as numbers of existing indicators and Destinations as active categories. Data sets are kept as per created order of Table 5, derived from Table 4 and represented in Table 7.

Table 6. Data Sets with Origins and Destinations as per Preliminary Order for Education $\left(\mathrm{S}_{3}\right)$

\begin{tabular}{|c|c|c|c|c|c|c|}
\hline & & Origins $\mathbf{S}_{31}$ & & Origins $S_{32}$ & & Demand \\
\hline \multirow{8}{*}{ 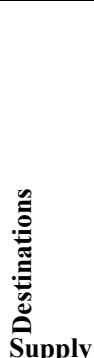 } & 1 & 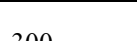 & 5 & & 4 & 9 \\
\hline & 2 & & 9 & 03 & 4 & 13 \\
\hline & 2 & 189 & 3 & 37 & 2 & 5 \\
\hline & 3 & 50 & & 45 & 2 & \\
\hline & 4 & 140 & 6 & 199 & 4 & 10 \\
\hline & 5 & 7 & 1 & 110 & 3 & 4 \\
\hline & 6 & 89 & 5 & 110 & 4 & 9 \\
\hline & & & 29 & & 21 & \\
\hline
\end{tabular}

Source: < http://redfame.com/> own case study 
Table 7. Data Sets with Origins and Destinations as per Created Order for Education $\left(\mathrm{S}_{3}\right)$

\begin{tabular}{|c|c|c|c|c|c|c|}
\hline & & Origins $S_{31}$ & & Origins $\mathrm{S}_{32}$ & & Demand \\
\hline \multirow{9}{*}{ 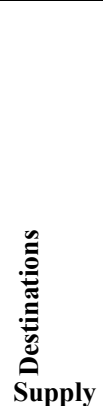 } & 1 & & 5 & & 4 & 9 \\
\hline & & 300 & 6 & 199 & 4 & 10 \\
\hline & 2 & 140 & & 91 & & \\
\hline & 3 & 180 & 9 & 45 & 2 & 11 \\
\hline & & 107 & 5 & & 3 & 8 \\
\hline & 4 & 89 & & 110 & & \\
\hline & 5 & 50 & 3 & 83 & 4 & 7 \\
\hline & 6 & & 1 & & 4 & 5 \\
\hline & & & 29 & & 21 & \\
\hline
\end{tabular}

Source: < http://redfame.com/> own case study

\subsection{Economy $\left(E_{5}\right)$-Aragatsotn Marz}

\subsubsection{Data Sets Retrievals}

Petrosyan (2016) describes the methodology of data sets retrieval from RA Ministry of Economy and directs to the summarized results of the first $\left(1^{\text {st }}\right)$ and the second $\left(2^{\text {nd }}\right)$ versions of Economy $\left(E_{5}\right)$-Aragatsotn Marz in Figure $5 \&$ Table 8.

Table $8.1^{\text {st }} \& 2^{\text {nd }}$ Versions of Data Retrievals for Economy $\left(\mathrm{E}_{5}\right)$ - Aragatsotn Marz

\begin{tabular}{|c|c|c|c|c|c|c|c|}
\hline \multicolumn{2}{|c|}{$\begin{array}{l}1^{\text {st }} \text { Version Economy }\left(E_{51}\right) \\
\text { Category }\end{array}$} & Summed numbers & & \multicolumn{2}{|c|}{$\begin{array}{l}2^{\text {nd }} \text { Version Economy }\left(E_{52}\right) \\
\text { Category }\end{array}$} & Summed numbers & \multirow[b]{2}{*}{ Indicators } \\
\hline No. & Name & Sub-category & Indicators & No. & Name & Sub-category & \\
\hline $\mathrm{E}_{511}$ & Structure & 4 & 52 & $\mathrm{E}_{521}$ & Tourism & 6 & 72 \\
\hline $\mathrm{E}_{512}$ & Legal Acts & 6 & 248 & $E_{522}$ & $\begin{array}{l}\text { Information } \\
\text { Technology }\end{array}$ & 3 & 86 \\
\hline$E_{513}$ & Projects & 4 & 129 & $\mathrm{E}_{523}$ & Market Controls & 9 & 325 \\
\hline $\mathrm{E}_{514}$ & Policies & 6 & 249 & $\mathrm{E}_{524}$ & Vacancies & 2 & 195 \\
\hline $\mathrm{E}_{515}$ & $\begin{array}{l}\text { Publication } \\
\text { Worldwide }\end{array}$ & 8 & 296 & $\begin{array}{l}E_{525} \\
E_{526}\end{array}$ & $\begin{array}{l}\text { Inspections } \\
\text { Informative }\end{array}$ & 6 & 165 \\
\hline$E_{516}$ & $\begin{array}{l}\text { Economic } \\
\text { Cooperation }\end{array}$ & 5 & 100 & & Contacts & 4 & 96 \\
\hline
\end{tabular}

Source: $<$ http://redfame.com/> own case study

4.2.2 Decision Making as Utility Function of Economy $\left(\mathrm{E}_{5}\right)$ Magnitude

Decision Making as Utility Function of Economy $\left(E_{5}\right)$ Magnitude is computed as per (2). The results of $\mathrm{DM}_{\mathrm{i}}$ are provided in Table 9 for the $1^{\text {st }}$ and the $2^{\text {nd }}$ versions of Economy $\left(\mathrm{E}_{5}\right)$ Magnitude-Aragatsotn Marz.

Table 9. $1^{\text {st }}$ and $2^{\text {nd }}$ Versions of Decision Making $\left(\mathrm{DM}_{\mathrm{i}}\right)$ Computation for Economy $\left(\mathrm{E}_{5}\right)$

\begin{tabular}{|c|c|c|c|c|c|c|c|c|}
\hline \multicolumn{4}{|c|}{$\begin{array}{l}1^{\text {st }} \text { Version } \\
\text { Magnitude (Category) }\end{array}$} & \multirow{2}{*}{$\mathbf{D M}_{\mathbf{i}}$} & \multicolumn{3}{|c|}{$\begin{array}{l}2^{\text {nd }} \text { Version } \\
\text { Magnitude (Category) }\end{array}$} & \multirow{2}{*}{$\mathbf{D M}_{\mathbf{i}}$} \\
\hline No. & Name & & Range & & No. & Name & Range & \\
\hline$E_{511}$ & Structure & & 6 & 13 & $\mathrm{E}_{521}$ & Tourism & 6 & 12 \\
\hline $\mathrm{E}_{512}$ & Legal Acts & & 2 & 41.33 & $\mathrm{E}_{522}$ & IT & 3 & 28.67 \\
\hline$E_{513}$ & Projects & & 4 & 32.25 & $\mathrm{E}_{523}$ & Market Controls & 2 & 36.11 \\
\hline $\mathrm{E}_{514}$ & Policies & & 1 & 41.5 & $\mathrm{E}_{524}$ & Vacancies & 1 & 97.5 \\
\hline $\mathrm{E}_{515}$ & Publication & & 3 & 37 & $\mathrm{E}_{525}$ & Inspections & 4 & 27.5 \\
\hline$E_{516}$ & $\begin{array}{l}\text { Worldwide } \\
\text { Cooperation }\end{array}$ & Economic & 5 & 25 & $\mathrm{E}_{526}$ & Informative Contacts & 5 & 24 \\
\hline
\end{tabular}

Source: Petrosyan (2016)

4.2.3 Constructions of Operation Research Approaches as Transportation Problem for Economy $\left(\mathrm{E}_{5}\right)$ Magnitude

A motivating approach is extracted from the paper of Petrosyan (2016) and the book of Gupta \&Cozzolino (1975). Data sets are depicted by Origins as numbers of existing indicators and Destinations as active categories of Economy ( $\mathrm{E}_{5}$ ) Magnitude. Data sets are sustained as per preliminary order, obtained from Table 8 and illustrated in Table 10.

Another smart approach is inspected in Table 11 through data sets representation with Origins as numbers of existing indicators and Destinations as active categories of Economy $\left(\mathrm{E}_{5}\right)$ Magnitude. Data sets are pertained as per created order of Table 9, acquired from Table 8 and represented in Table 11. 
Table 10. Data Sets with Origins and Destinations as per Preliminary Order for Economy $\left(\mathrm{E}_{5}\right)$

\begin{tabular}{|c|c|c|c|c|c|c|}
\hline & & Orig & & Origins $E_{52}$ & & Demand \\
\hline \multirow{11}{*}{ 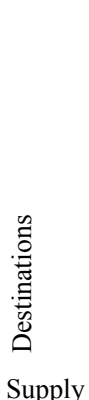 } & 1 & & 4 & & 6 & 10 \\
\hline & & 52 & & 72 & & \\
\hline & 2 & & 6 & & 3 & 9 \\
\hline & & 248 & & 86 & & \\
\hline & 3 & & 4 & & 9 & 13 \\
\hline & 4 & 129 & 6 & 325 & ? & 8 \\
\hline & & 249 & & 195 & 2 & 0 \\
\hline & 5 & & 8 & & 6 & 14 \\
\hline & 6 & 296 & 4 & 165 & 4 & 8 \\
\hline & & 100 & & 96 & & \\
\hline & & & 32 & & 30 & \\
\hline
\end{tabular}

Source: < http://redfame.com/> own case study

Table 11. Data Sets with Origins and Destinations as per Created Order for Economy $\left(\mathrm{E}_{5}\right)$

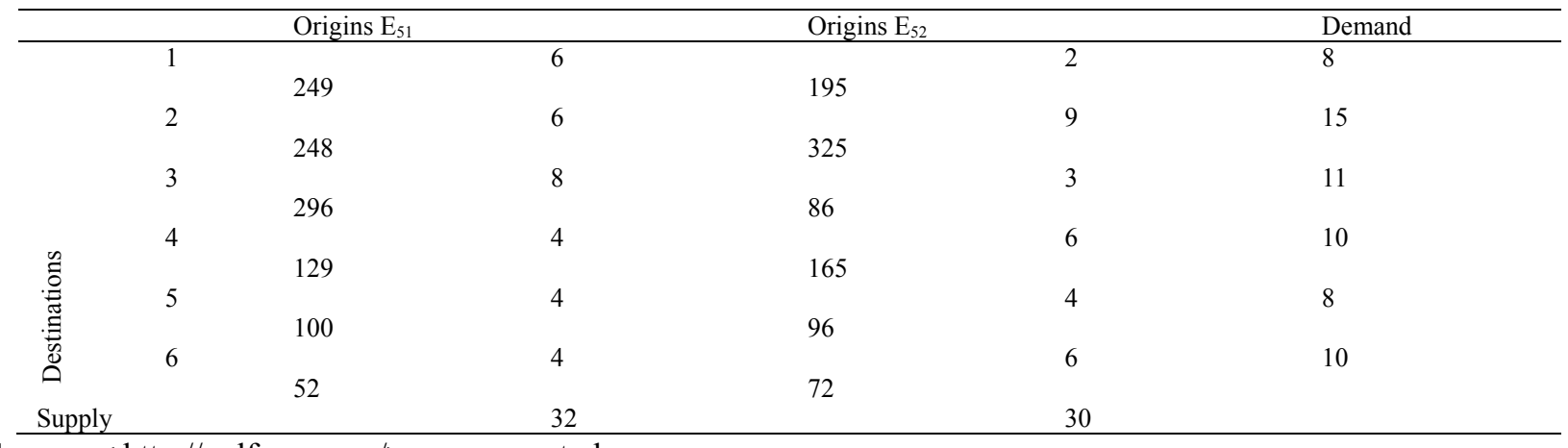

Source: < http://redfame.com/> own case study

\subsection{Land $\left(N_{1}\right)$ - Hadrut Marz and Air $\left(N_{3}\right)$-Martakert Marz}

4.3.1 Data Sets Retrievals

Petrosyan (2016) portrays the methodology of data sets retrieval from RA Ministry of Nature Protection (MNP) and leads to the summarized results of the first $\left(1^{\text {st }}\right)$ Version as Air $\left(\mathrm{N}_{3}\right)$-Martakert Marz (Figure 6$)$ and the second $\left(2^{\text {nd }}\right)$ version as Land $\left(\mathrm{N}_{1}\right)$-Hadrut Marz (Figure 7) in Table 12.

Table 12. Data Retrievals for $1^{\text {st }}$ Version of Air $\left(\mathrm{N}_{3}\right)$-Martakert Marz\& $2^{\text {nd }}$ Version of Land $\left(\mathrm{N}_{1}\right)$-Hadrut Marz

\begin{tabular}{|c|c|c|c|c|c|c|c|}
\hline \multicolumn{2}{|c|}{$\begin{array}{l}1^{\text {st }} \text { Version Air }\left(\mathrm{N}_{31}\right) \\
\text { Category }\end{array}$} & \multicolumn{2}{|c|}{ Summed numbers } & \multicolumn{2}{|c|}{$\begin{array}{l}2^{\text {nd }} \text { Version Land }\left(\mathrm{N}_{12}\right) \\
\text { Category }\end{array}$} & \multicolumn{2}{|c|}{ Summed numbers } \\
\hline No. & Name & Sub-category & Indicators & No. & Name & Sub-category & Indicators \\
\hline $\mathrm{N}_{311}$ & Structure & 3 & 82 & $\mathrm{~N}_{121}$ & $\begin{array}{l}\text { International } \\
\text { Cooperation }\end{array}$ & 2 & 49 \\
\hline $\mathrm{N}_{312}$ & Regulation & 8 & 273 & $\mathrm{~N}_{122}$ & Projects & 6 & 208 \\
\hline $\mathrm{N}_{313}$ & Reports & 3 & 47 & $\mathrm{~N}_{123}$ & $\begin{array}{l}\text { Natural } \\
\text { Resources }\end{array}$ & 4 & 128 \\
\hline $\mathrm{N}_{314}$ & Vacancies & 3 & 26 & $\mathrm{~N}_{124}$ & $\begin{array}{l}\text { Inspectorial } \\
\text { Activities }\end{array}$ & 8 & 157 \\
\hline $\mathrm{N}_{315}$ & Atmosphere & 4 & 230 & $\mathrm{~N}_{125}$ & $\begin{array}{l}\text { Informative } \\
\text { Contacts }\end{array}$ & 3 & 74 \\
\hline $\mathrm{N}_{316}$ & Publications & 5 & 367 & $\mathrm{~N}_{126}$ & $\begin{array}{l}\text { Nature } \\
\text { Protection }\end{array}$ & 4 & 175 \\
\hline
\end{tabular}

Source: < http://redfame.com/> own case study

4.3.2 Decision Making as Utility Function of Air $\left(\mathrm{N}_{3}\right)$-Land $\left(\mathrm{N}_{1}\right)$ Magnitude

Decision Making as Utility Function of Air $\left(\mathrm{N}_{3}\right)$ \& Land $\left(\mathrm{N}_{1}\right)$ Magnitude is calculated as per (2). The results of DM are provided in Table 13 for the $1^{\text {st }}$ Version of Air $\left(\mathrm{N}_{3}\right)$-Martakert Marz and the $2^{\text {nd }}$ version of Land $\left(\mathrm{N}_{1}\right)$-Hadrut $M a r z$. 
Table 13. $1^{\text {st }} \& 2^{\text {nd }}$ Versions of Decision Making $\left(\mathrm{DM}_{\mathrm{i}}\right)$ Computation for Air $\left(\mathrm{N}_{3}\right) \&$ Land $\left(\mathrm{N}_{1}\right)$

\begin{tabular}{|c|c|c|c|c|c|c|c|}
\hline \multicolumn{3}{|c|}{$\begin{array}{l}1^{\text {st }} \text { Version / Air }\left(\mathrm{N}_{3}\right) \\
\text { Magnitude (Category) }\end{array}$} & $\mathbf{D M}_{\mathbf{i}}$ & \multicolumn{3}{|c|}{$\begin{array}{l}2^{\text {nd }} \text { Version / Land }\left(\mathrm{N}_{1}\right) \\
\text { Magnitude (Category) }\end{array}$} & $\mathbf{D M}_{\mathbf{i}}$ \\
\hline $\mathrm{N}_{311}$ & Structure & 4 & 27.33 & $\mathrm{~N}_{121}$ & International Cooperation & 5 & 24.5 \\
\hline $\mathrm{N}_{312}$ & Regulation & 3 & 34.13 & $\mathrm{~N}_{122}$ & Projects & 3 & 34.67 \\
\hline $\mathrm{N}_{313}$ & Reports & 5 & 15.67 & $\mathrm{~N}_{123}$ & Natural Resources & 4 & 32 \\
\hline $\mathrm{N}_{314}$ & Vacancies & 6 & 8.67 & $\mathrm{~N}_{124}$ & Inspectorial Activities & 6 & 19.63 \\
\hline $\mathrm{N}_{315}$ & Atmosphere & 2 & 57.5 & $\mathrm{~N}_{125}$ & Informative Contacts & 1 & 83 \\
\hline $\mathrm{N}_{316}$ & Publications & 1 & 73.4 & $\mathrm{~N}_{126}$ & Nature Protection & 2 & 43.75 \\
\hline
\end{tabular}

Source: Petrosyan (2016)

4.3.3 Constructions of Operation Research Approaches as Transportation Problem for Air $\left(\mathrm{N}_{3}\right)$-Land $\left(\mathrm{N}_{1}\right)$ Magnitude

An encouraging approach is attained from the paper of Petrosyan (2016) and the book of Gupta \&Cozzolino (1975). Data sets are exposed by Origins as numbers of existing indicators and Destinations as active categories of Air $\left(\mathrm{N}_{3}\right)$-Land $\left(\mathrm{N}_{1}\right)$ Magnitude. Data sets are preserved as per preliminary order, acquired from Table 12 and typified in Table 14.

Table 14. Data Sets with Origins-Destinations for Preliminary Order for Air $\left(\mathrm{N}_{3}\right)$-Land $\left(\mathrm{N}_{1}\right)$

\begin{tabular}{|c|c|c|c|c|c|c|}
\hline & & Orig & & Origins $\mathrm{N}_{12}$ & & Demand \\
\hline \multirow{8}{*}{ 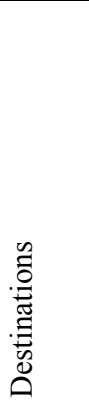 } & 1 & & 3 & & 2 & 5 \\
\hline & & 82 & & 49 & & \\
\hline & 2 & & 8 & & 6 & 14 \\
\hline & 3 & 273 & 3 & 208 & 4 & 7 \\
\hline & & 47 & & 128 & & \\
\hline & 4 & 26 & 3 & 157 & 8 & 11 \\
\hline & 5 & & 4 & & 3 & 7 \\
\hline & 6 & 230 & 5 & 74 & 4 & 9 \\
\hline Supply & & 367 & 26 & 175 & 27 & \\
\hline
\end{tabular}

Source: $<$ http://redfame.com/> own case study

Another optimistic approach is examined in Table 15 through data sets representation with Origins as numbers of existing indicators and Destinations as active categories of Air $\left(\mathrm{N}_{3}\right)$-Land $\left(\mathrm{N}_{1}\right)$ Magnitude. Data sets are pertained as per created order of Table 13, acquired from Table 12 and represented in Table 15.

Table 15. Data Sets with Origins \& Destinations as per Created Order for Air $\left(\mathrm{N}_{3}\right)$-Land $\left(\mathrm{N}_{1}\right)$

\begin{tabular}{|c|c|c|c|c|c|c|}
\hline & & Orig & & Orig & & Demand \\
\hline & 1 & & 5 & & 3 & 8 \\
\hline & 2 & 367 & 4 & 74 & 4 & 8 \\
\hline & & 230 & & 175 & & \\
\hline & 3 & & 8 & & 6 & 14 \\
\hline & 4 & 273 & 2 & 208 & 4 & 7 \\
\hline & & 82 & & 128 & & \\
\hline 氜 & 5 & & 3 & & 2 & 5 \\
\hline 㺃 & 6 & & 3 & & 8 & 11 \\
\hline Supply & & 26 & 26 & 151 & 27 & \\
\hline
\end{tabular}

Source: $<$ http://redfame.com/> own case study

\subsection{Employment (ACASP)-Yerevan Marz}

\subsubsection{Data sets retrievals}

Petrosyan (2016) explains the methodology of data sets retrieval from State Employment Agency (SEA) and pilots the summarized results of the first $\left(1^{\text {st }}\right)$ and the second $\left(2^{\text {nd }}\right)$ versions of Employment $(\mathrm{F})$-Yerevan Marz in Figure $8 \&$ Table 16. 
Table $16.1^{\text {st }} \& 2^{\text {nd }}$ Versions of Data Retrievals for Employment (F)-Yerevan Marz

\begin{tabular}{|c|c|c|c|c|c|c|c|}
\hline \multirow{2}{*}{\multicolumn{2}{|c|}{$\begin{array}{l}1^{\mathrm{st}} \text { Version Employment }\left(\mathrm{F}_{1}\right) \\
\text { Category }\end{array}$}} & \multirow{2}{*}{\multicolumn{2}{|c|}{ Summed numbers }} & \multicolumn{4}{|c|}{$2^{\mathrm{ntu}}$ Version Employment $\left(\mathbf{F}_{2}\right)$} \\
\hline & & & & \multirow{2}{*}{\multicolumn{2}{|c|}{ Category }} & \multicolumn{2}{|c|}{ Summed numbers } \\
\hline No. & Name & Sub-category & Indicators & No. & & Sub-category & Indicators \\
\hline $\mathrm{F}_{11}$ & Structure & 2 & 13 & $\mathrm{~F}_{21}$ & Jobseekers & 6 & 62 \\
\hline $\mathrm{F}_{12}$ & Legislation & 2 & 9 & $\mathrm{~F}_{22}^{11}$ & Employers & 1 & 9 \\
\hline $\mathrm{F}_{13}^{12}$ & Membership & 2 & 7 & $\mathrm{~F}_{23}^{22}$ & Programs & 2 & 57 \\
\hline $\mathrm{F}_{14}^{13}$ & Publication & 2 & 7 & $\mathrm{~F}_{24}$ & Labour Market & 5 & 39 \\
\hline $\mathrm{F}_{15}$ & $\begin{array}{l}\text { Announcements } \\
\text { News }\end{array}$ & 2 & 43 & $\mathrm{~F}_{25}$ & $\begin{array}{l}\text { International } \\
\text { Cooperation }\end{array}$ & 3 & 23 \\
\hline $\mathrm{F}_{16}$ & $\begin{array}{l}\text { Informative } \\
\text { Contacts }\end{array}$ & 4 & 38 & $\mathrm{~F}_{26}$ & $\begin{array}{l}\text { Analyses } \\
\text { Researches }\end{array}$ & 4 & 91 \\
\hline
\end{tabular}

Source: $<$ http://redfame.com/> own case study

4.4.2 Decision Making as Utility Function of Employment (F)

Decision Making as Utility Function of Employment (F) Magnitude is determined as per (2). The results of $\mathrm{DM}_{\mathrm{i}}$ are offered in Table 17 for the $1^{\text {st }}$ and the $2^{\text {nd }}$ versions of Employment (F) Magnitude-Yerevan Marz.

Table 17. $1^{\text {st }}$ and $2^{\text {nd }}$ Versions of Decision Making $\left(\mathrm{DM}_{\mathrm{i}}\right)$ Computation for Employment $(\mathrm{F})$

\begin{tabular}{|c|c|c|c|c|c|c|c|}
\hline \multicolumn{3}{|c|}{$\begin{array}{l}1^{\mathrm{st}} \text { Version } \\
\text { Magnitude (Category) }\end{array}$} & $\mathbf{D M}_{\mathbf{i}}$ & \multicolumn{3}{|c|}{$\begin{array}{l}\text { 2"10 }^{\text {nersion }} \\
\text { Magnitude (Category) }\end{array}$} & $\mathbf{D M}_{\mathbf{i}}$ \\
\hline $\mathrm{F}_{11}$ & Structure & 3 & 6.5 & $\mathrm{~F}_{21}$ & Jobseekers & 3 & 10.33 \\
\hline$F_{12}^{11}$ & Legislation & 4 & 4.5 & $\mathrm{~F}_{22}$ & Employers & 4 & 10 \\
\hline$F_{13}^{12}$ & Membership & 6 & 3.5 & $\mathrm{~F}_{23}$ & Programs & 2 & 11.5 \\
\hline $\mathrm{F}_{14}$ & Publication & 5 & 3.5 & $\mathrm{~F}_{24}$ & Labour Market & 5 & 7.8 \\
\hline $\mathrm{F}_{15}$ & Announcements / News & 1 & 21.5 & $\mathrm{~F}_{25}$ & International Cooperation & 6 & 7.67 \\
\hline$F_{16}^{10}$ & Informative Contacts & 2 & 9.5 & $\mathrm{~F}_{26}^{20}$ & Analyses and Researches & 1 & 22.75 \\
\hline
\end{tabular}

Source: Petrosyan (2016)

4.4.3 Constructions of Operation Research Approaches as Transportation Problem for Employment (F) Magnitude

An appealing approach is originated from the paper of Petrosyan (2016) and the book of Gupta \& Cozzolino (1975). Data sets are displayed by Origins as numbers of existing indicators and Destinations as active categories of Employment (F) Magnitude. Data sets are conserved as per preliminary order, obtained from Table 16 and expressed in Table 18.

Another attractive approach is characterized in Table 19 through data sets representation with Origins as numbers of existing indicators and Destinations as active categories of Employment (F) Magnitude. Data sets are exhibited as per created order of Table 17, acquired from Table 16 and conveyed in Table 19.

Table 18. Data Sets with Origins \& Destinations as per Preliminary Order for Employment (F)

\begin{tabular}{|c|c|c|c|c|c|c|}
\hline & & \multirow{3}{*}{13} & & Origins $F_{2}$ & & Demand \\
\hline \multirow{7}{*}{ 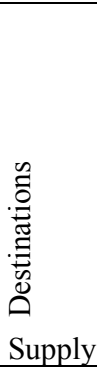 } & 1 & & 2 & \multirow{2}{*}{62} & 6 & \\
\hline & \multirow[t]{2}{*}{2} & & 2 & & 1 & 3 \\
\hline & & \multirow{2}{*}{$\begin{array}{l}9 \\
7\end{array}$} & 2 & \multirow{2}{*}{$\begin{array}{l}9 \\
57\end{array}$} & 2 & 4 \\
\hline & 4 & & 2 & & 5 & 7 \\
\hline & 5 & 7 & 2 & 39 & 3 & 5 \\
\hline & 6 & \multirow{2}{*}{$\begin{array}{l}43 \\
38\end{array}$} & 4 & \multirow{2}{*}{$\begin{array}{l}23 \\
91\end{array}$} & 4 & 8 \\
\hline & & & 14 & & 21 & \\
\hline
\end{tabular}

Source: $<$ http://redfame.com/> own case study

Table 19. Data Sets with Origins and Destinations as per Created Order for Employment (F)

\begin{tabular}{|c|c|c|c|c|c|c|}
\hline & & Origins $\mathrm{F}_{1}$ & & Origins $F_{2}$ & & Demand \\
\hline \multirow{7}{*}{ 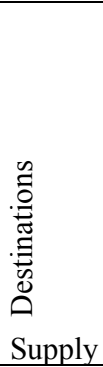 } & 1 & \multirow{2}{*}{43} & 2 & \multirow{2}{*}{$\mathrm{H}_{11}$} & 4 & \\
\hline & 2 & & 4 & & 2 & 6 \\
\hline & 3 & 30 & 2 & & 6 & 8 \\
\hline & 4 & 13 & 2 & 62 & 1 & 3 \\
\hline & 5 & 3 & 2 & & 5 & 7 \\
\hline & 6 & 1 & 2 & 39 & 3 & 5 \\
\hline & & 1 & 14 & 25 & 21 & \\
\hline
\end{tabular}

Source: $<$ http://redfame.com/> own case study 


\section{Actualization}

\subsection{Matrix Representations}

The book of Gupta \& Cozzolino (1975) defines the steps in the depiction of transportation problem. Data sets are recaptured from the paper of Petrosyan (2016) through implementation of operation research approaches to the characterized ACASP. The sequences of Education $\left(\mathrm{S}_{3}\right)$, Economy $\left(\mathrm{E}_{5}\right)$, Air $\left(\mathrm{N}_{3}\right)$-Land $\left(\mathrm{N}_{1}\right)$ and Employment $(\mathrm{F})$ representatives are derived in Table 20 and Table 21. Origins and destinations are computed by (3), (4) and (5), while transformation of indicators, categories and magnitudes are correspondingly interrelated to supply and demand applications with matrix illustrations of transportation assignments.

Table 20. Matrix through Origins \& Destinations with Supply \& Demand

\begin{tabular}{|c|c|c|c|c|c|c|c|c|c|c|c|c|}
\hline Sequence & 1 & & 2 & & 3 & & 4 & & 5 & & 6 & \\
\hline $\mathrm{S}_{31}$ & & 5 & & 9 & & 3 & & 6 & & 1 & & 5 \\
\hline $\mathrm{S}_{32}$ & & 4 & & 4 & & 2 & & 4 & & 3 & & 4 \\
\hline & 83 & & 37 & & 45 & & 199 & & 110 & 8 & 91 & 4 \\
\hline $\mathrm{E}_{51}$ & 52 & 4 & 248 & 6 & 129 & 4 & 249 & 6 & 296 & 8 & 100 & 4 \\
\hline $\mathrm{E}_{52}$ & 72 & 6 & 86 & 3 & 325 & 9 & 195 & 2 & 165 & 6 & 96 & 4 \\
\hline $\mathrm{N}_{31}$ & 82 & 3 & 273 & 8 & 47 & 3 & 26 & 3 & 230 & 4 & 267 & 5 \\
\hline $\mathrm{N}_{12}$ & 02 & 2 & 215 & 6 & 41 & 4 & 20 & 8 & 250 & 3 & I0 & 4 \\
\hline $\mathrm{F}_{1}$ & 49 & 2 & 208 & 2 & 128 & 2 & וכנו & 2 & 14 & 2 & $1 / 5$ & 2 \\
\hline $\mathrm{F}_{2}$ & 62 & 6 & 9 & 1 & 57 & 2 & 39 & 5 & 23 & 3 & 91 & 4 \\
\hline
\end{tabular}

Source: $<$ http://redfame.com/> own case study

Table 21. Organized Matrix through Origins \& Destinations with Supply \& Demand

\begin{tabular}{lllllllllllll}
\hline Sequence & $\mathbf{1}$ & & $\mathbf{2}$ & & $\mathbf{3}$ & $\mathbf{4}$ & $\mathbf{5}$ & & $\mathbf{6}$ & \\
\hline $\mathrm{S}_{31}$ & 300 & 5 & 140 & 6 & 189 & 9 & 89 & 5 & 50 & 3 & 7 & 1 \\
$\mathrm{~S}_{32}$ & 199 & 4 & 9 & 4 & 45 & 2 & 110 & 3 & 83 & 4 & 37 & 4 \\
$\mathrm{E}_{51}$ & 249 & 6 & 248 & 6 & 296 & 8 & 129 & 4 & 10 & 4 & 52 & 4 \\
$\mathrm{E}_{52}$ & 195 & 2 & 325 & 9 & 86 & 3 & 165 & 6 & 96 & 4 & 72 & 6 \\
$\mathrm{~N}_{31}$ & 367 & 5 & 230 & 4 & 273 & 8 & 82 & 3 & 47 & 3 & 26 & 3 \\
$\mathrm{~N}_{12}$ & 74 & 3 & 175 & 4 & 208 & 6 & 128 & 4 & 49 & 2 & 157 & 8 \\
$\mathrm{~F}_{1}$ & 43 & 2 & 38 & 4 & 13 & 2 & 9 & 2 & 7 & 2 & 7 & 2 \\
$\mathrm{~F}_{2}$ & 91 & 4 & 57 & 2 & 62 & 6 & 9 & 1 & 39 & 5 & 23 & 3 \\
\hline
\end{tabular}

Source: $<$ http://redfame.com/> own case study

\subsection{North-West Corner Rule (NWCR)}

Gupta and Cozzolino (1975) implied North-West Corner Rule (NWCR) in Tables 22 \& 23. North-West Corner Rule (NWCR) is imposed through performance of three (3) main steps for solving the $1^{\text {st }}$ order (Table 22) and the $2^{\text {nd }}$ order (Table 23) matrices as:

Step 1: Choose the northwest corner cell; Step 2: Make the possible largest shipment;

Step 3: Regulate supply \& requirement numbers. Go to Step 1 until the assignment is solved.

Table 22. ${ }^{\text {st }}$ Order Matrix computation for North-West Corner Rule $\left(\mathrm{NWCR}_{1}\right)$

\begin{tabular}{|c|c|c|c|c|c|c|c|c|c|c|c|c|c|}
\hline Seq & 1 & & 2 & & 3 & & 4 & & 5 & & 6 & & Supply \\
\hline $\mathrm{S}_{31}$ & $\begin{array}{l}29 \\
300\end{array}$ & 5 & 180 & 9 & 50 & 3 & 140 & 6 & & 1 & 80 & 5 & 29,0 \\
\hline$S_{32}$ & 3 & 4 & $\begin{array}{l}18 \\
3\end{array}$ & 4 & J & 2 & 199 & 4 & 110 & 3 & 09 & 4 & $21,18,0$ \\
\hline$E_{51}$ & & 4 & 21 & 6 & 11 & 4 & & 6 & 110 & 8 & 31 & 4 & $32,11,0$ \\
\hline $\mathbf{E}_{52}$ & 52 & 6 & 248 & 3 & $\begin{array}{l}129 \\
18\end{array}$ & 9 & $\begin{array}{l}249 \\
12\end{array}$ & 2 & 296 & 6 & 100 & 4 & $30,12,0$ \\
\hline$N_{31}$ & 12 & 3 & 277 & 8 & & 3 & 21 & 3 & $\begin{array}{l}105 \\
2\end{array}$ & 4 & 96 & 5 & $26,2,0$ \\
\hline $\mathbf{N}_{12}$ & 82 & 2 & 273 & 6 & 47 & 4 & & 8 & $\begin{array}{l}230 \\
27\end{array}$ & 3 & 367 & 4 & 27,0 \\
\hline$F_{1}$ & & 2 & 200 & 2 & 120 & 2 & 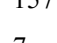 & 2 & $\begin{array}{l}14 \\
1\end{array}$ & 2 & 13 & 2 & $14,13,0$ \\
\hline$F_{2}$ & 13 & 6 & 9 & 1 & 7 & 2 & 7 & 5 & & 3 & $\begin{array}{l}30 \\
21 \\
21\end{array}$ & 4 & 21,0 \\
\hline Dem & $\begin{array}{l}62 \\
32,3,0\end{array}$ & & $\begin{array}{l}9 \\
39,\end{array}$ & & & & $\begin{array}{l}39 \\
36,\end{array}$ & & 30,2 & & $\begin{array}{l}91 \\
34,2\end{array}$ & & \\
\hline
\end{tabular}


Source: $<$ http://redfame.com/> own case study

Min $\mathrm{ZNWCR}_{1}=300 * 29+83 * 3+37 * 18+248 * 21+129 * 11+325 * 18+195 * 12+26 * 24+230 * 2+74 * 27+43 * 1+$ $38 * 13+91 * 21=29962$

Table 23. $2^{\text {nd }}$ Order Organized Matrix computation for North-West Corner Rule $\left(\mathrm{NWCR}_{2}\right)$

\begin{tabular}{|c|c|c|c|c|c|c|c|c|c|c|c|c|c|}
\hline Seq & $\frac{1}{1}$ & & 2 & & 3 & & 4 & & 5 & & 6 & & Supply \\
\hline $\mathbf{S}_{31}$ & 29 & 5 & 140 & 6 & 180 & 9 & 80 & 5 & 50 & 3 & & 1 & 29,0 \\
\hline$S_{32}$ & 3 & 4 & 18 & 4 & 109 & 2 & & 3 & 50 & 4 & 1 & 4 & $21,18,0$ \\
\hline $\mathbf{E}_{51}$ & 199 & 6 & $\begin{array}{l}91 \\
21\end{array}$ & 6 & $\begin{array}{l}45 \\
11\end{array}$ & 8 & 110 & 4 & 83 & 4 & 37 & 4 & $32,11,0$ \\
\hline $\mathbf{E}_{52}$ & 249 & 2 & 248 & 9 & $\begin{array}{l}296 \\
18\end{array}$ & 3 & $\begin{array}{l}129 \\
12\end{array}$ & 6 & 100 & 4 & 52 & 6 & $30,12,0$ \\
\hline $\mathbf{N}_{31}$ & 193 & 5 & 325 & 4 & 86 & 8 & $\begin{array}{l}165 \\
24\end{array}$ & 3 & $\begin{array}{l}96 \\
2\end{array}$ & 3 & 72 & 3 & $26,2,0$ \\
\hline$N_{12}$ & 367 & 3 & 230 & 4 & 273 & 6 & 82 & 4 & $\begin{array}{l}47 \\
27\end{array}$ & 2 & 20 & 8 & 27,0 \\
\hline$F_{1}$ & 74 & 2 & 175 & 4 & 208 & 2 & 128 & 2 & $\begin{array}{l}49 \\
1\end{array}$ & 2 & $\begin{array}{l}157 \\
13\end{array}$ & 2 & $14,13,0$ \\
\hline$F_{2}$ & 43 & 4 & 38 & 2 & 13 & 6 & 9 & 1 & & 5 & 21 & 3 & 21,0 \\
\hline Dem & $\begin{array}{l}91 \\
32,3,0\end{array}$ & & & & $\begin{array}{l}62 \\
29,\end{array}$ & & $\begin{array}{l}9 \\
36,2\end{array}$ & & & 1,0 & $\begin{array}{l}23 \\
34,2\end{array}$ & & \\
\hline
\end{tabular}

Source: $<$ http://redfame.com/> own case study

Min $\mathrm{ZNWCR}_{2}=300 * 29+199 * 3+91 * 18+248 * 21+296 * 11+86 * 18+165 * 12+82 * 24+47 * 2+49 * 27+7 * 1+$ $7 * 13+23 * 21=26893$

\subsection{Low Cost Cell Rule (LCCR)}

Gupta and Cozzolino (1975) follows three (3) key steps through implementation of Low Cost Cell Rule (LCCR) for solving the $1^{\text {st }}$ order (Table 24 ) and $2^{\text {nd }}$ order (Table 25) matrices as:

Step 1: Pick the cell with the lowest unit cost; Step 2: Make the possible largest shipment;

Step 3: Regulate supply \& requirement numbers. Go to Step 1 until the assignment is solved.

Table 24. $1^{\text {st }}$ Order Matrix computation for Low Cost Cell Rule $\left(\mathrm{LCCR}_{1}\right)$

\begin{tabular}{|c|c|c|c|c|c|c|c|c|c|c|c|c|c|}
\hline Seq & 1 & & 2 & & 3 & & 4 & & 5 & & 6 & & Supply \\
\hline$S_{31}$ & $\begin{array}{l}18 \\
300\end{array}$ & 5 & $\begin{array}{l}11 \\
189\end{array}$ & 9 & 50 & 3 & 140 & 6 & 7 & 1 & 89 & 5 & 29,110 \\
\hline$S_{32}$ & 83 & 4 & 21 & 4 & 政 & 2 & 199 & 4 & & 3 & & 4 & 21,0 \\
\hline $\mathbf{E}_{51}$ & 52 & 4 & $\begin{array}{l}7 \\
248\end{array}$ & 6 & $\begin{array}{l}8 \\
129\end{array}$ & 4 & $\begin{array}{l}17 \\
249\end{array}$ & 6 & 296 & 8 & 100 & 4 & $32,25,17,0$ \\
\hline $\mathbf{E}_{52}$ & 72 & 6 & 86 & 3 & 325 & 9 & $\begin{array}{l}19 \\
195\end{array}$ & 2 & $\begin{array}{l}11 \\
165\end{array}$ & 6 & 96 & 4 & $30,11,0$ \\
\hline $\mathbf{N}_{31}$ & 82 & 3 & 273 & 8 & 47 & 3 & 26 & 3 & $\begin{array}{l}19 \\
230\end{array}$ & 4 & $\begin{array}{l}7 \\
367\end{array}$ & 5 & $26,7,0$ \\
\hline$N_{12}$ & 49 & 2 & 208 & 6 & 128 & 4 & 157 & 8 & 74 & 3 & $\begin{array}{l}27 \\
175\end{array}$ & 4 & 27,0 \\
\hline $\mathbf{F}_{1}$ & 14 & 2 & 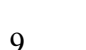 & 2 & & 2 & 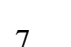 & 2 & 43 & 2 & 38 & 2 & 14,0 \\
\hline $\mathbf{F}_{2}$ & & 6 & 9 & 1 & 21 & 2 & & 5 & & 3 & & 4 & 21,0 \\
\hline Dem & $32,18,0$ & & 39,28 & & 29, & & 36,1 & & 30 , & 1,0 & 34,2 & & \\
\hline
\end{tabular}

Source: $<$ http://redfame.com/> own case study

Min $\mathrm{ZLCCR}_{1}=300 * 18+189 * 11+37 * 21+248 * 7+129 * 8+249 * 17+195 * 19+165 * 11+230 * 19+367 * 7+175 * 27$ $+13 * 14+57 * 21=33820$ 
Table 25. $2^{\text {nd }}$ Order Organized Matrix computation for Low Cost Cell Rule $\left(\mathrm{LCCR}_{2}\right)$

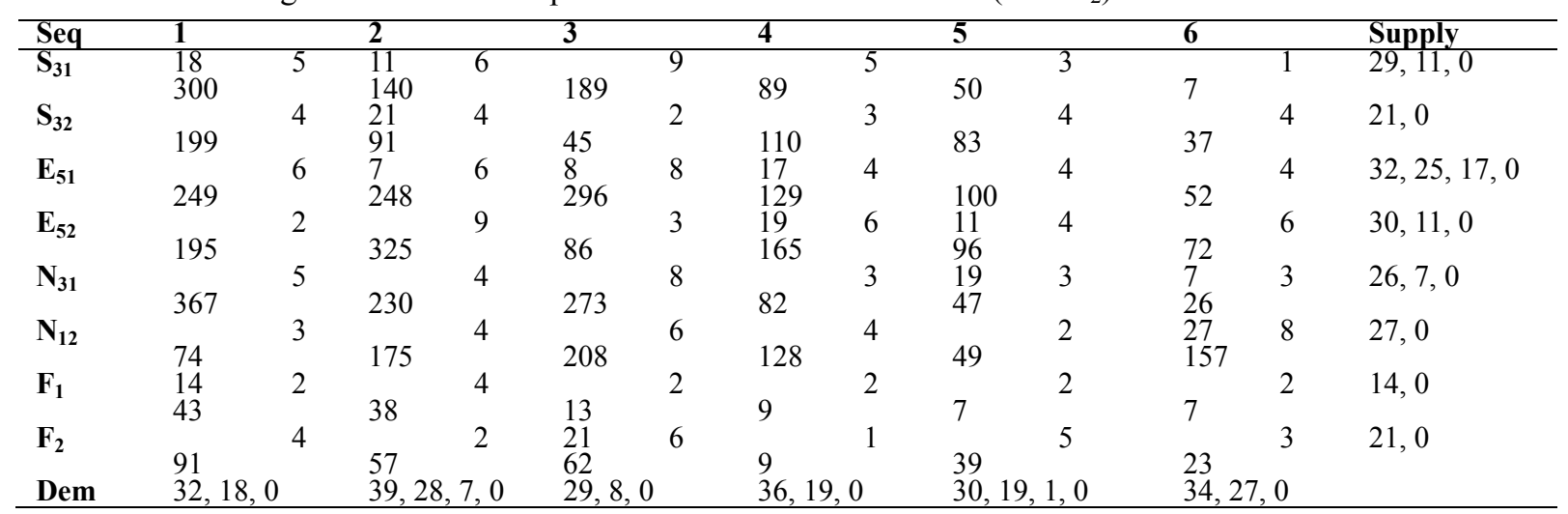

Source: $<$ http://redfame.com/> own case study

Min ZLCCR2 $=300 * 18+140 * 11+91 * 21+248 * 7+296 * 8+129 * 17+165 * 19+96 * 11+47 * 19+26 * 7+27 * 157+$ $43 * 13+62 * 21=26686$

\section{Discussion}

An awesome approach is applied not only to decide the order of importance as per defined biodiversity concept, but also to represent decision making process as per operation research approaches, particularly transportation assignments through origins and destinations with supply and demand applications.

In order to decide the importance of the order for Education, Economy and Natural Protection Ministries, operation research methods are applied by the basic order, i.e. $1^{\text {st }}$ order and complied order, i.e. $2^{\text {nd }}$ order. The results of total costs (MinZ) are retrieved from Tables 22-25 and depicted in Table 26 through appliances of North-West Corner Rule (NWCR) and Low Cost Cell Rule (LCCR).

Table 26. $1^{\text {st }} \& 2^{\text {nd }}$ order with implementation of NWCR \& LCCR

\begin{tabular}{lll}
\hline MinZ & $\mathbf{1}^{\text {st }}$ order & $\mathbf{2}^{\text {nd }}$ order \\
\hline North-West Corner Rule (NWCR) & 29962 & 26893 \\
Low Cost Cell Rule (LCCR) & 33820 & $\mathbf{2 6 6 8 6}$ \\
\hline
\end{tabular}

Source: $<$ http://redfame.com/> own case study

Petrosyan (2016) paper coincides with the current paper and provides the specified sequences of RA ministerial distributions towards improvements of employment within Armenian Composite Appraising Supportive Progress (ACASP).

\section{Conclusion}

Petorsyan $(2014,2010)$ describes Sustainable Development as an innovative concept viewed as Composite Appraising Supportive Progress of Armenia (ACASP). Biodiversity concept is an extra topic having an immense power on public management and employment. Techniques from old literature review of operation research studies (Gupta \& Cozzolino, 1975) are implied on the modern concepts of CASP (Petrosyan, 2014, 2015a-c) because the literature gap existence is resolved combining main digested approaches.

A motivating approach is recounted not only to choose the order of significance as per biodiversity concept, but also to typify decision making process through operation research techniques, particularly transportation assignments as per origins and destinations with supply and demand applications. Social, economic and environmental impacts optimize sequences within Education $\left(\mathrm{S}_{3}\right)$, Economy $\left(\mathrm{E}_{5}\right)$, Air $\left(\mathrm{N}_{3}\right)$ \& Land $\left(\mathrm{N}_{1}\right)$ Ministries. Seven (7) phases of Operation Research (OR) studies (Hillier \& Liberman, 2001) are characterized through nine (9) procedures of composite progressive indicators - CPI (Petrosyan, 2015d \& 2016).

Public Management is inspected in terms of Employment (F) as an executive impression of ACASP. Petrosyan (2014) demonstrates typical relations of three (3) biodiversity stages in Table 1. Proposed public management of ACASP is depicted in the papers of Petrosyan (2015 a, b, c \& 2016) as per magnitudes, categories and indicators. North-West Corner Rule (NWCR) and Low Cost Cell Rule (LCCR) are applied to supervise the executive plan through Employment (F) performance in three (3) dimensional ways of Education $\left(\mathrm{S}_{3}\right)$, Economy $\left(\mathrm{E}_{5}\right)$ and Land $\left(\mathrm{N}_{1}\right)$-Air $\left(\mathrm{N}_{3}\right)$ Magnitudes. Petrosyan (2016) and the current paper emphasize on sequences of the most imperative categories with the proposed model of ACASP as:

$\begin{array}{lllc}\text { Genes: } & \text { Society }(\mathrm{S}) & \text { Education }\left(\mathrm{S}_{3}\right): & \text { Legislations - International Cooperation } \\ \text { Species: } & \text { Economy }(\mathrm{E}) & \text { Economy }\left(\mathrm{E}_{5}\right): & \text { Policy - Vacancies }\end{array}$


Ecosystems: $\quad$ Nature $(\mathrm{N}) \quad$ Air $\left(\mathrm{N}_{3}\right) \&$ Land $\left(\mathrm{N}_{1}\right)$ : Publications - Informative

Functions: $\quad$ ACASP Employment $(\mathrm{F}): \quad$ Announcements-Analyses \& Researches

Accompanying investigations are advised to lead improvements of Employment (F) magnitude towards combinations of the additional ministerial magnitudes for prescribed ACASP. Further research is required in public management to advance Armenian economy and to improve Employment (F) magnitude within proposed ACASP.

\section{References}

Arakelyan, M., \& Parham, J. (2008). The Geographic Distribution of Turtles in Armenia and the Nagorno-Karabakh Republic (Artsakh).Chelonian Conservation \& Biology, 7(1), 70-77. http://dx.doi.org/10.2744/CCB-0664.1

ARMSTAT (2015). National Statistical Service of Armenia. Retrieved from http://armstat.am/en/

Balcerzak, A. P. (2015). Europe 2020 Strategy and Structural Diversity between Old and New Member States. Application of Zero Notarization Method for Dynamic Analysis in the Years 2004-2013, Economics and Sociology, 8(2), 190-210. http://dx.doi.org/10.14254/2071-789X.2015/8-2/14

Deriglazova, L., \& Minasyan, S. (2011). Nagorno-Karabakh: the Paradoxes of Strength and Weakness in an Asymmetric Conflict. Caucasus Institute Research Papers, \# 3, June 2011.-Yerevan: Caucasus Institute, 104.

Gupta, S. K., \& Cozzolino, J. M. (1975). Fundamentals of Operation Research for Management. Holden-Day Inc., ISBN: 0-8162-3476-0, 405.

Hillier, F. S., \& Lieberman, G. J. (2001). Introduction to Operations Research. Seventh Edition. McGraw-Hill Higher Education. ISBN: 0072321695, 1237.

Levett, R. (1998). Sustainability indicators-integrating quality of life and environmental protection. Journal of the Royal Statistical Society: Series A (Statistics in Society), 161(3), 291-302. http://dx.doi.org/10.1111/1467-985X.00109

Lyytimaki, J., \& Rosenstrom, U. (2008). Skeletons out of the closet: effectiveness of conceptual frameworks for communicating sustainable development indicators. Sustainable Development, 16(5), 301-313. http://dx.doi.org/10.1002/sd.330

Midgley, G., \& Reynolds, M. (2004). Systems/operational research and sustainable development: Towards a new agenda. Sustainable Development, 12(1), 56-64. http://dx.doi.org/10.1002/sd.218

Mirthy, R. P. (2007). Operation Research.Second Edition.New Age International (P) Limited Publishers. ISBN (13): 978-81-224-2944-2, 716.

Nijkamp, P., \& Vindigni, G. (2003). Impact assessment of qualitative policy scenarios: Comparative Case Study on Land Use in Sicily. Management of Environmental Quality: An International Journal, 14(1), 108-133. http://dx.doi.org/10.1108/14777830310460423

NKRSTAT (2015). National Statistical Service of Nagorno-Karabakh Republic. Retrieved from: http://www.stat-nkr.am/en/

Petrosyan A. F. (2014). Appraising Biodiversity in Supportive Progress Using GIS Means. LAP LAMBERT, Academic Publishing Company in Saarbrucken, Germany, ISBN: 978-3-659-34415-2, 668.

Petrosyan, A. F. (2005). Economic valuation of biodiversity loss: the case of Mediterranean forest. Participation on the sixth meeting of the "Développementd'Actions pour le Marketing et la Gestion post-évènements"-DAMAGE. Athens, Greece, October.

Petrosyan, A. F. (2010). A Model for Incorporated Measurement of Sustainable Development Comprising Remote Sensing Data and Using the Concept of Biodiversity. Journal of Sustainable Development, 3(2), 9-26. http://dx.doi.org/10.5539/jsd.v3n2p9

Petrosyan, A. F. (2015a). Smart Development through Biodiversity Concept in Armenian Composite Appraising Supportive Progress (ACASP), International Journal of Business and Industrial Marketing, American Association for Science and Technology (AASCIT), 1(4), 64-77. http://www.aascit.org/journal/ijbim

Petrosyan, A. F. (2015b). Indicative Review Through Biodiversity Concept in Construction of Composite Appraising Supportive Progress (CASP) of Armenia, American Journal of Environmental Policy and Management, American Association for Science and Tech (AASCIT), 1(4), 57-66. http://www.aascit.org/journal/ajepm

Petrosyan, A. F. (2015c). Approximation of Indicators in Society Magnitude as per Armenian Composite Appraising Supportive Progress (ACASP), International Journal of Investment Management and Financial Innovations, 
American Association for Science \& Tech (AASCIT), 1(4), 77-88. http://www.aascit.org/journal/ijimfi

Petrosyan, A. F. (2015d). Procedures Designing Composite Progressive Indicators, International Journal of Econometrics and Financial Management, Science and Education Publishing, 3(2), 104-109. $\mathrm{http}: / /$ pubs.sciepub.com/ijefm/3/2/8/

Petrosyan, A. F. (2016). Public Employment and Management as per Ministerial Education, Economy and Natural Protection according to Armenian Composite Supportive Progress (ACASP), Journal of Public Management Research, Macrothink Institute, ISSN 2377-3294, December 2016, 2(2), 22.

Riasi, A., \& Pourmiri, S. (2016). Examples of Unsustainable Tourism in Middle East. Environmental Management and Sustainable Development, 5(1), 69-85. http://dx.doi.org/10.5296/emsd.v5i1.8705

Runge, M. C. (2012). Decision Trees \& Utility Theory. USGS Patuxent Wildlife Research Center. Advanced SDM Practicum. NCTC, 12-16 March 2012: 44pp.

Walton, J. S., El-Haram, M., Castillo, N. H., Horner, R. M. W., Price, A. D. F., \& Hardcastle, C. (2005). Integrated assessment of urban sustainability, Engineering Sustainability, 158(2), 57-65.

http://dx.doi.org/10.1680/ensu.2005.158.2.57

\section{(c) EY}

This work is licensed under a Creative Commons Attribution 3.0 License. 